\title{
Susceptibility of Aedes aegypti populations to pyriproxyfen in the Federal District of Brazil
}

\author{
Bruno Lopes Carvalho ${ }^{[1]}$, Rayssa Nádia Leite Germano ${ }^{[2]}$, Kátia Maria Leal Braga ${ }^{[2]}$, \\ Evaldo Rosano Ferreira de Araújo ${ }^{[2]}$, Douglas de Almeida Rocha ${ }^{[1]}$ and Marcos Takashi Obara ${ }^{[3]}$
}

\author{
[1]. Universidade de Brasília, Programa de Pós-Graduação Stricto Sensu em Medicina Tropical, Brasília, DF, Brasil. \\ [2]. Ministério da Saúde, Secretaria de Vigilância em Saúde, Laboratório de Entomologia Médica, Brasília, DF, Brasil. \\ [3]. Universidade de Brasília, Laboratório de Parasitologia e Biologia de Vetores, \\ Programa de Pós-Graduação Stricto Sensu em Medicina Tropical, Brasília, DF, Brasil.
}

\begin{abstract}
Introduction: In Brasilia, pyriproxyfen (PPF; $0.01 \mathrm{mg} / \mathrm{L}$ ) has been used for the larval control of Aedes aegypti mosquitoes since 2016. Information on the susceptibility of Ae. aegypti to PPF, and the development of resistance in populations from the Federal District of Brazil (FD) is limited. It is essential to monitor the susceptibility of Ae. aegypti to insecticides in order to improve vector control strategies. This study aimed to evaluate the susceptibility of Ae. aegypti populations from five areas of Brasilia to PPF. Methods: We performed dose-response tests to estimate the emergence inhibition and resistance ratio of each field population, including the Rockefeller reference population. We also analyzed egg positivity, and the density and mortality of larvae and pupae. Results: Populations from Vila Planalto $\left(\mathrm{RR}_{50}=1.7\right)$, Regiment Guards Cavalry $\left(\mathrm{RR}_{50}=2.5\right)$, and Sub-secretary of Justice Complex $\left(\mathrm{RR}_{50}=3.7\right)$ presented high susceptibility to $\mathrm{PPF}$, while the $\mathrm{RR}$ values of populations from Lago Norte $\left(\mathrm{RR}_{50}=7.7\right)$ and Varjão $\left(\mathrm{RR}_{50}=5.9\right)$ were moderately high, suggesting the emergence of insipient resistance to PPF in Brasilia. At $30 \mathrm{ng} / \mathrm{mL}$, the highest larvae mortality rate was $2.7 \%$ for the population from Lago Norte, while that of pupae was $92.1 \%$ for Varjão and Vila Planalto. Conclusions: The five populations of Ae. aegypti from the FD are susceptible to PPF and there is a need to monitor the susceptibility of Ae. aegypti in new areas of the FD.
\end{abstract}

Keywords: Aedes aegypti. Susceptibility. Resistance. Pyriproxyfen.

\section{INTRODUCTION}

Arboviruses (Arthropod-borne viruses) are of great importance for public health due to their high impact on health and the economy ${ }^{1,2,3}$. The main viruses transmitted by mosquitoes are urban yellow fever (YFV), dengue (DENV), chikungunya (CHINKV), and Zika (ZIKV). Some researchers ${ }^{4}$ have reported the occurrence of at least one of these viruses in 146 countries, for which the main vectors are mosquitoes Aedes aegypti (Linnaeus, 1762) and Aedes albopictus (Skuse, 1894).

Ae. aegypti is the primary vector of arboviruses in Brazil and is spread in all Federative Units of the country ${ }^{5}$. Environmental, socioeconomic, biological, and non-biological factors favor the dispersion and proliferation of this species, in addition

\footnotetext{
Corresponding author: Dr. Marcos Takashi Obara.

e-mail: marcos.obara@gmail.com

(D) 0000-0001-6872-0096

Received 19 November 2019

Accepted 09 January 2020
}

to its urban habits, which are associated with anthropophilia, endophilia, endophagia, domiciliation, and oviposition strategy in artificial breeding sites. This increases the transmission of $\operatorname{arboviruses}^{6,7,8,9,10,11}$.

Historically, Ae. aegypti was controlled with organochlorine dichlorodiphenyltrichlorethane (DDT), organophosphates (malathion, fenitrothion), carbamate (bendiocarb), pyrethroids (cypermethrin, deltamethrin, and alphacypermethrin), biological insecticides (Bacillus thunrigiensis), and growth-regulating insecticides (diflubenzuron, novaluron, and pyriproxyfen) . $^{5}$

The continuous and systematic use of the same product over a long period can select resistant individuals, compromising vectorcontrol. Currently, resistance to organophosphates and pyrethroids has been reported in several populations of Ae. aegypti, including populations in the Federal District of Brazil (FD) ${ }^{12,13,14,15,16,17}$.

In 1999, the National Network for Monitoring the Resistance of Ae. aegypti to Insecticides (MoReNAa) began to monitor the insecticide resistance of Ae. aegypti in Brazil, leading to changes in the products used in the National Program for Dengue Control (PNCD) $)^{18}$. 
Temephos has been gradually replaced by diflubenzuron and novaluron since 2009. After this, the use of juvenile hormone analog pyriproxyfen (PPF) started in several Brazilian cities. In 2012, Ae. aegypti populations from Planaltina/FD were resistant to temephos and less susceptible to PPF, suggesting cross-resistance between Temephos and $\mathrm{PPF}^{19}$.

In the FD, large-scale use of PPF began in $2016^{20,21}$. After 4 years, there is little information on the susceptibility profile of Ae. aegypti to PPF. This information is critical for improving control activities of Ae. aegypti. Thus, the objective of this study was to analyze the susceptibility of Ae. aegypti populations from five areas of the FD to PPF.

\section{METHODS}

\section{Areas of study}

The Ae. aegypti populations were derived from five areas of Brasilia, located in the Center-West region of Brazil. We established the selection criteria for the areas based on the use of PPF, during the last 3 years, carried out by the Environmental Surveillance Directorate (DIVAL). Thus, the selected areas were: i) Vila

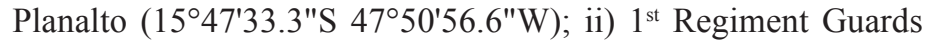

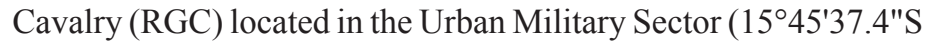

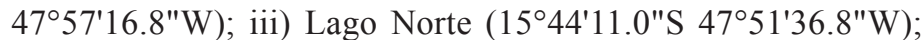
iv) Varjão (15 $\left.42^{\prime} 30.7^{\prime \prime S} 47^{\circ} 52^{\prime} 45.4^{\prime \prime W}\right)$, and v) Sub-secretary of Justice Complex of the Federal District (SUAG-DF) $\left(15^{\circ} 46^{\prime} 34.0\right.$ "S $\left.47^{\circ} 56^{\prime} 26.9^{\prime \prime W}\right)$, located in the Industry and Supply Sector.

\section{Field populations}

We installed 60 ovitraps $^{22}$, with the addition of $10 \%$ hay to increase egg capture yield ${ }^{23}$. All traps remained in each area for 2 weeks in the peridomicile environment. The traps were installed in the grounds of houses, protected from rain, with limited human and animal movement $\mathrm{t}^{24}$. A volume of $20 \mathrm{~mL}$ of feno solution (10\%) was added per trap to attract gravid females. The traps were replaced at the end of the first week and collected in the second week. The pallets containing eggs were collected, identified, and stored vertically inside a polystyrene box to prevent the eggs from being crushed or damaged. We transported the boxes to the Laboratório de Entomologia Médica, Secretaria de Vigilância em Saúde, Ministério da Saúde/SVS/MS. Then, we identified ${ }^{25}$ and counted eggs, which were classified as hatchlings, withered, and viable ${ }^{26}$, and estimated egg positivity index (EPI) and egg density (EDI). Pallets with eggs were submerged in dechlorinated water and hatched larvae were transferred to basins containing $1 \mathrm{~L}$ of dechlorinated water. Larvae were fed with $3 \mathrm{mg}$ of natural Guabi ${ }^{\circledR}$ shredded cat food, which was added every 3 days. After the emergence of adults, we offered a $10 \%$ sugar solution to males and females.

Three-days after their emergence, mosquitoes were fed with bird blood (Gallus gallus domesticus) every $48 \mathrm{~h}$, according to Protocol No. 85/2018 of the Commission for Ethics in Animal Use (CEUA) of the University of Brasilia. Insectaries were maintained under controlled temperature $\left(27 \pm 2^{\circ} \mathrm{C}\right)$ and humidity $(70 \pm 15 \%)$ conditions. We used F1, F2, or F3 Ae aegypti generations for the trials, according to the guidelines of the World Health Organization (WHO) ${ }^{27}$.

\section{Susceptible population}

We used the Rockefeller population of Ae. aegypti, from the Laboratorio de Entomologia/Diretoria de Vigilância Ambiental/ DIVAL/SES/DF.

\section{Chemical product}

We used 97\% technical grade Pyriproxyfen (PPF) provided by ROGAMA NEOGENV®.

\section{Biological tests}

Biological bioassays were performed according as previously described $^{27}$, using nine concentrations ranging from 0.001 to $30 \mathrm{ng} / \mathrm{mL}$. For each dose, a total of 270 third-stage larvae were exposed, including the control group. Larvae were selected homogeneously to standardize their physiological and chronological age. Then, the larvae were placed in $400 \mathrm{~mL}$ cups containing $250 \mathrm{~mL}$ of distilled water, covered with a fine mesh net attached to the edge with an elastic alloy. All larvae remained at rest for approximately $30 \mathrm{~min}$ for acclimatization. Subsequently, we removed $1 \mathrm{~mL}$ of water from each beaker. Then, $1 \mathrm{ml}$ of PPF solution was added in nine increasing concentrations and the mixture was homogenized with a glass rod. We fed the larvae with Guabi ${ }^{\circledR}$ Natural Feed every 72 h. Mortality was recorded every $48 \mathrm{~h}$ by a single researcher using a specific form; we completed this work when all pupae had emerged into adults. The mortality criteria were as follows: i) larvae and pupae unable to ascend to the surface or show diving reactions when the water was disturbed; ii) immobile larvae and pupae when stimulated with a needle in their siphon or cervical region ${ }^{27,28}$ and, iii) adults that did not complete development and were unable to completely emerge from the pupa during the emergence phase. Live adults were considered as those totally free of their exuviae and able to fly or walk when gently touched. We performed all trials in triplicate on four different days and prepared an equal number of controls with the same amount of water and $1 \mathrm{~mL}$ of alcohol. Mortality, as well as the emergence of adults, was recorded when all the specimens in the control condition had emerged as adults. We discarded assays in which adult emergence was less than $90 \%$ in the control group. When inhibition was between 91 and $99 \%$, the Abbott formula was used for correction ${ }^{27}$. We controlled temperature $\left(25-30^{\circ} \mathrm{C}\right)$ and relative air humidity $(70-80 \%)$ with a heater and a conventional air humidifier.

\section{Statistical analysis}

We used the Polo PC program (Polo-PC, LeOra Software, Berkeley, CA ${ }^{29}$ (Raymond 1985$)^{30}$ to estimate the emergence inhibition doses of adults from the reference and field lines. The resistance ratios (RR) were determined through the $\mathrm{EI}_{50}$ quotient of the field population by the $\mathrm{EI}_{50}$ of the susceptible population, as well as the $95 \%$ confidence interval (CI 95\%) of each population ${ }^{31}$. We also estimated the mortality of larvae and pupae ${ }^{32,33}$. The angular coefficient of the dose-response curve was calculated for each population using Graph-Pad Prism version 6.1 for Windows ${ }^{34}$. The criterion adopted for resistance classification was $\mathrm{RR}<5$, indicating a susceptible field population; an RR between 5 and 10 indicated moderate resistance; and an $R R>10$ indicated high resistance ${ }^{27}$. 


\section{RESULTS}

The ovitraps obtained 5,966 eggs from Ae. aegypti, of which 4,171 were viable, 1,212 withered, and 583 hatched. The Figure 1 shows the OPI and EDI of the traps installed to obtain Ae. aegypti eggs. The highest OPI (95\%) was recorded for the traps deployed in Vila Planalto, while the lowest values were recorded for those deployed in Varjão, whose OPI was 36\%. Although Vila Planalto presented the highest OPI, the EDI was low (34).

We exposed a total of 14,580 Ae. aegypti larvae to PPF. The Lago Norte and Varjão Ae. aegypti populations presented moderate resistance, with $R_{50}$ values of 7.7 and 5.9, respectively. The populations from Vila Planalto $\left(\mathrm{RR}_{50}=1.7\right), \mathrm{RCG}\left(\mathrm{RR}_{50}=2.5\right)$, and SUAG $\left(\mathrm{RR}_{50}=3.7\right)$ presented high susceptibility to PPF, as shown in Table 1.
Table 2 presents data on the Rockefeller reference population, which obtained the highest EI compared to other field populations; thus, at a $30 \mathrm{ng} / \mathrm{mL}$ dose, the researchers recorded an average $99 \% \mathrm{EI}$ of adults in the Rockefeller reference lineage. At this dose, the mean EI of adults in the field populations of Ae. aegypti was $92 \%$ for Vila Planalto and Varjão, $90 \%$ for Lago Norte, $89 \%$ for SUAG, and $87 \%$ for RCG.

Figure 2 shows the mortality rates of larvae and pupae. The mortality of larvae exposed to PPF was low, while it was high for pupae, with values above $90 \%$ in most field populations. The gradient values of the Ae. aegypti populations from five areas of the FD are shown in Figure 3. We observed gradient patterns similar to the reference population in those from Vila Planalto and SUAG. Although the Ae. aegypti populations from Varjão and Lago Norte were similar, when compared to the reference population, the RCG population showed less homogeneity.
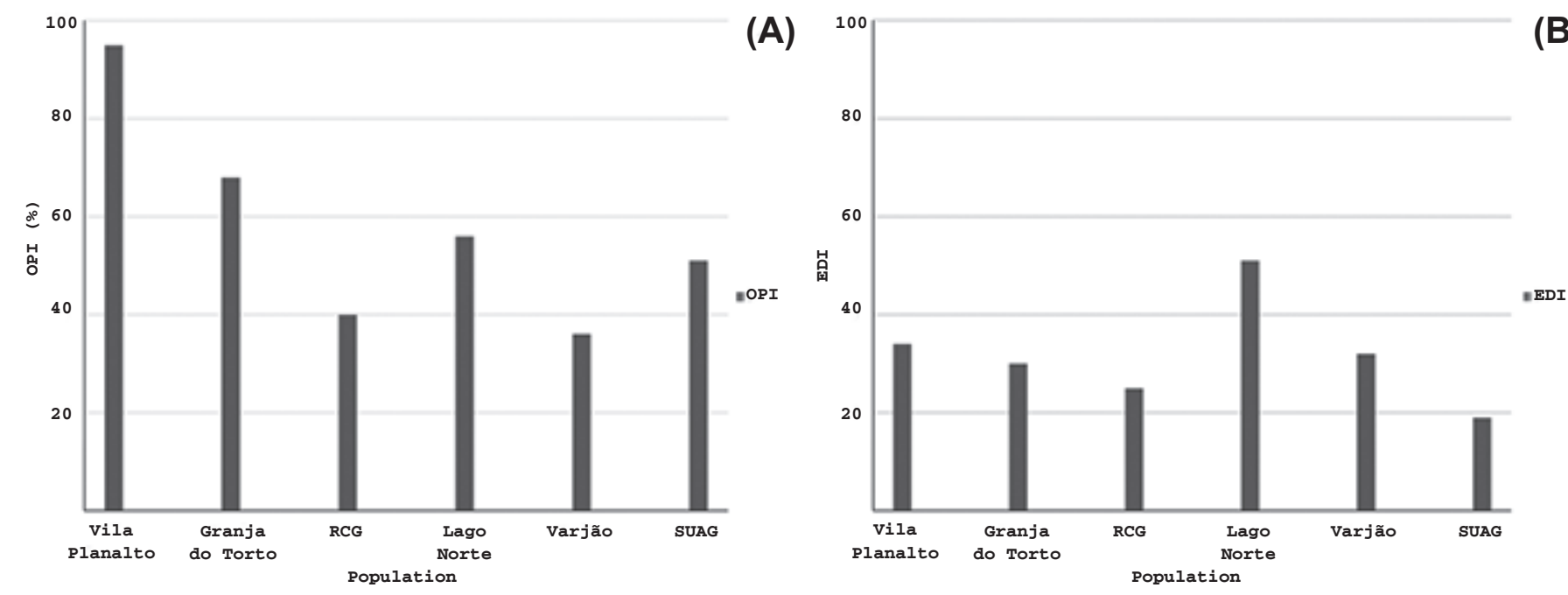

FIGURE 1: Ovitrap positive index (OPI) and egg density index (EDI) per positive trap in five areas of the Federal District of Brazil, from January to April 2017. (A) OPI: ovitrap positivity index, obtained by the percentage of positive paddles; and (B) EDI: egg density index obtained by the ratio between egg number and positive paddles.

TABLE 1: Estimates of inhibition emergence $50 \%$ (IE50) and resistance ratio of Aedes aegypti mosquito populations exposed to different doses of juvenile pyriproxyfen (PPF) hormone analog in 2018.

\begin{tabular}{lccc}
\hline Population & Generation & El50\%(Cl95\%) & Slope \\
\hline Rockfeller & & $0.059(0.005-0.199)$ & 0.576 \\
Lago Norte & F1 & $0.56(0.083-1.848)$ & 0.546 \\
Varjão & F1-F2 & $0.353(0.043-1.388)$ & 0.541 \\
SUAG & F1-F2-F3 & $0.219(0.007-1.055)$ & 0.501 \\
RCG & F1-F2 & $0.151(0.002-0.772)$ & 0.35 \\
Vila Planalto & F1-F2-F3 & $0.106(0.015-0.311)$ & 3.7 \\
\end{tabular}

Confidence Interval 95\%. El: emergence inhibition; RCG: $1^{\text {st }}$ Regiment Guards Cavalry; SUAG: Sub-secretary of Justice Complex of the Federal Distritct; RR: resistance ratio. 


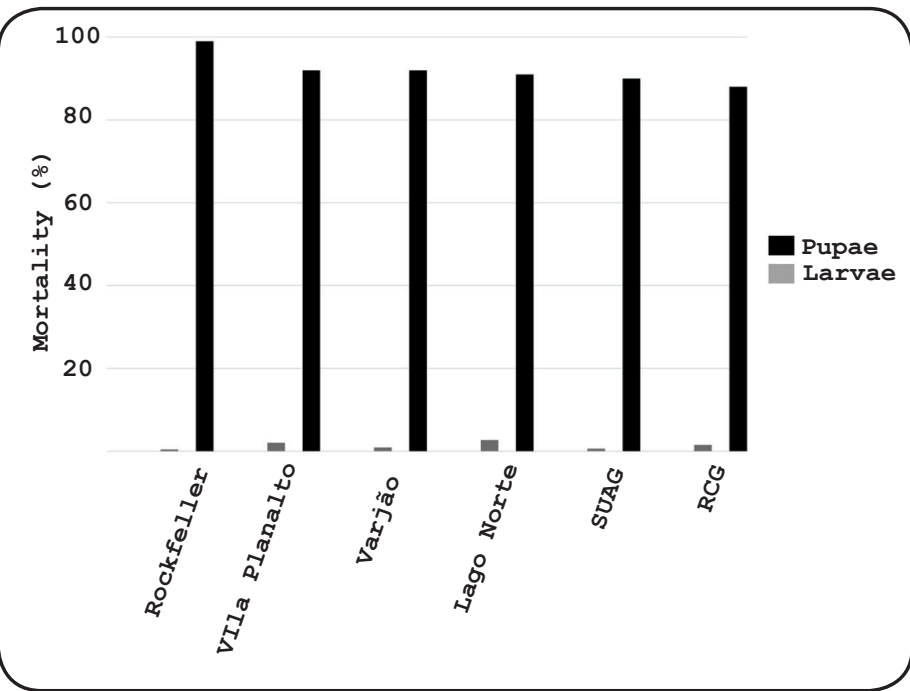

FIGURE 2: Mortality distribution of Aedes aegypti larvae and pupae from populations exposed to different doses of pyriproxyfen in 2018.

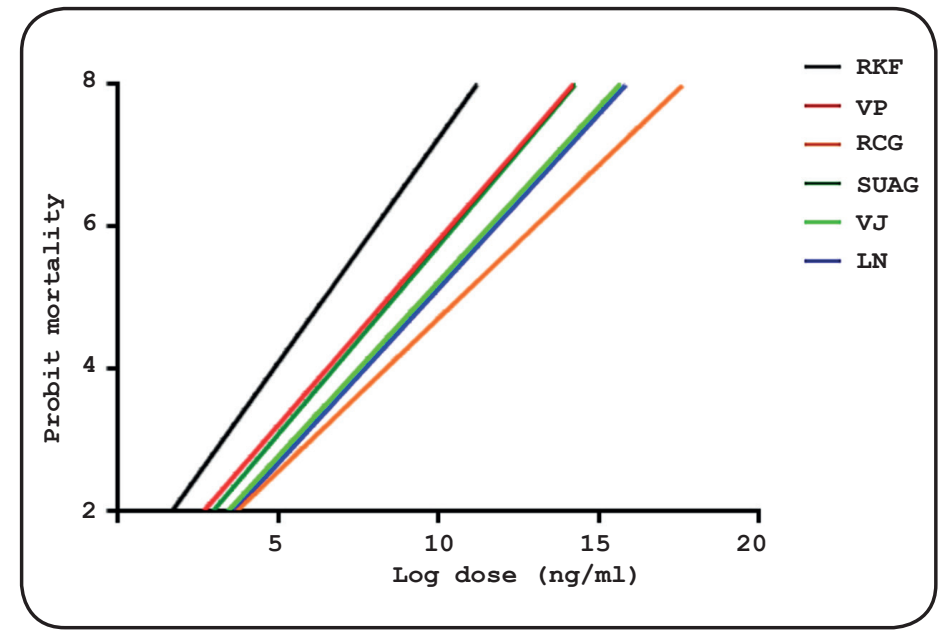

FIGURE 3: Mortality of Aedes aegypti populations on a logarithmic scale, in response to juvenile pyriproxyfen hormone analog in 2018. RKF: Rockefeller; VP: Vila Planalto; RCG: $1^{\circ}$ Cavalry Regiment Guards; SUAG: Complex of the Undersecretary of Justice of the Federal District; VJ: Varjão; LN: Lago Norte.

TABLE 2: Emergence inhibition of Aedes aegypti populations exposed to different doses of juvenile pyriproxyfen (PPF) hormone analog in 2018.

\begin{tabular}{|c|c|c|c|c|c|c|c|c|c|c|c|c|}
\hline \multirow{2}{*}{$\begin{array}{l}\text { Doses } \\
\text { (ng/ml) }\end{array}$} & \multicolumn{2}{|c|}{ Rockefeller } & \multicolumn{2}{|c|}{ Lago Norte } & \multicolumn{2}{|c|}{ Varjão } & \multicolumn{2}{|c|}{ SUAG } & \multicolumn{2}{|c|}{ RCG } & \multicolumn{2}{|c|}{ Vila Planalto } \\
\hline & n $(2,430)$ & ${ }^{*} \mathrm{EI}$ & $n(2,430)$ & ${ }^{*} \mathrm{EI}$ & n $(2,430)$ & ${ }^{*} \mathrm{EI}$ & n $(2,430)$ & ${ }^{*} \mathrm{EI}$ & $n(2,430)$ & ${ }^{*} \mathrm{EI}$ & n $(2,430)$ & ${ }^{*} \mathrm{EI}$ \\
\hline 0.001 & 270 & 24 & 270 & 12 & 270 & 14 & 270 & 12 & 270 & 17 & 270 & 16 \\
\hline 0.01 & 270 & 51 & 270 & 38 & 270 & 44 & 270 & 33 & 270 & 58 & 270 & 57 \\
\hline 0.05 & 270 & 57 & 270 & 41 & 270 & 51 & 270 & 48 & 270 & 60 & 270 & 64 \\
\hline 0.07 & 270 & 66 & 270 & 46 & 270 & 57 & 270 & 55 & 270 & 65 & 270 & 67 \\
\hline 1 & 270 & 76 & 270 & 52 & 270 & 61 & 270 & 58 & 270 & 67 & 270 & 71 \\
\hline 5 & 270 & 82 & 270 & 58 & 270 & 65 & 270 & 69 & 270 & 71 & 270 & 76 \\
\hline 7 & 270 & 87 & 270 & 74 & 270 & 81 & 270 & 69 & 270 & 78 & 270 & 82 \\
\hline 10 & 270 & 89 & 270 & 81 & 270 & 80 & 270 & 82 & 270 & 79 & 270 & 91 \\
\hline 30 & 270 & 99 & 270 & 90 & 270 & 92 & 270 & 89 & 270 & 87 & 270 & 92 \\
\hline
\end{tabular}

*El: emergence inhibition (\%).

\section{DISCUSSION}

Here, we evaluated the susceptibility of Ae. aegypti from the Federal District to the PPF. The results found for Vila Planalto $\left(\mathrm{RR}_{50}=1.7\right), \mathrm{RCG}\left(\mathrm{RR}_{50}=2.5\right)$ and $\mathrm{SUAG}\left(\mathrm{RR}_{50}=3.7\right)$ corroborate those reported by Leyva et al. (2010), who conducted technical PPF assays (97\%) on four Ae. aegypti populations from Cuba. In that study, the RR values were $3.4,0.9,0.5$, and 1 for populations of SANtem F13, Boyeros, Cotorro, and 10 de Octubre, respectively.

Low levels of resistance were detected in two populations of Ae. aegypti from Barreiras (in the state of Bahia/BA [RR=1.4], and Bauru/SP [RR=3.6] following exposure to PPF, classifying them as susceptible to $\mathrm{PPF}^{35}$. In Martinique, Ae. aegypti populations also presented $\mathrm{RR}=2.2$ in trials with $98.7 \%$ technical $\mathrm{PPF}^{36}$. Four-years later, Marcombe and collaborators detected susceptibility to PPF in eight populations of Ae. albopictus in the United States, obtaining
RR values ranging from 1 to $2.36^{37}$. Despite the low RR values, periodic and systematic monitoring of Ae. aegypti populations over time in response to PPF is essential.

Dose-response tests with PPF revealed that $30 \mathrm{ng} / \mathrm{mL}$ inhibited the emergence of adults by $99 \%\left(\mathrm{EI}_{99}\right)$ in the Rockefeller line; therefore, the diagnostic dose $\left(\mathrm{DD}=\mathrm{EI}_{99 \times 2}\right)$ was estimated to be $60 \mathrm{ng} / \mathrm{mL}$. No diagnostic-dose laboratory tests were performed; however, had they been conducted, the populations of Lago Norte $\left(\mathrm{RR}_{50}=7.7\right)$ and Varjão $\left(\mathrm{RR}_{50}=5.9\right)$ would have been considered susceptible, since they are likely to have inhibited $100 \%$ emergence. However, the moderately high values of $\mathrm{RR}_{50}$ indicated a probable change in susceptibility of Ae. aegypti populations, suggesting the emergence of resistance populations in Brasilia.

In Brazil, monitoring the insecticide resistance of Ae. aegypti populations has had an important impact on arboviruses 
epidemiology. Populations of Ae. aegypti with high levels of resistance contribute to the emergence of dengue outbreaks with high magnitude. In Campo Grande, the highest RR values (above 50 for deltamethrin) revealed that the period with the highest incidence of dengue coincides with the detection of Ae. aegypti populations with high resistance ${ }^{38}$.

Large urban centers with a greater flow of people, a history of mosquitoes and arbovirus circulation, are also determining factors for the increased spread of resistance. In 2019, the municipality of Palmas $\left(\mathrm{RR}_{50}=28\right)$ had the highest probable number of dengue cases, unlike Caseara $\left(\mathrm{RR}_{50}=1.6\right)$, which is less urbanized and is remote of other major centers urban areas ${ }^{17}$.

Thus, the monitoring of insecticide resistance in Ae. aegypti populations should be continuous and periodic for the rational management of adulticides and larvicides used to control mosquito populations, and for reducing local or large-scale resistance.

In this study, the mortality of larvae from field populations ranged from 0.6 to $2.0 \%$, and that of pupae ranged from 99 to $88 \%$, at a 30 $\mathrm{ng} / \mathrm{mL}$ dose. This can be explained by the activity of PPF during the pupal phase, when comparative studies of field simulations between the Rockefeller and Itabuna/Bahia populations are conducted, with mortality rates of 97.9 and $95.1 \%$, respectively ${ }^{39}$. Conversely, the larval mortality rate o was only 2.1 and $4.9 \%$, respectively. Others studies $^{40}$ have reported similar results under laboratory conditions, with higher mortality in Ae. aegypti pupae.

The mortality rate of Ae. aegypti pupae treated with PPF was $100 \%$ with the 0.2 and $1 \mathrm{ppm}$ doses $^{41}$. Another study using commercial PPF showed that doses lower than $0.01 \mathrm{ppb}$ resulted in $98.5 \%$ pupal mortality ${ }^{42}$. Therefore, PPF is highly effective at inhibiting the emergence of adults, hindering the formation of wings, and the development of reproductive organs and external genitalia ${ }^{43}$.

Currently, the Brazilian Ministry of Health ${ }^{44}$ uses the Larval Index Rapid Assay for Aedes aegypti (LIRAa) to direct actions for the control of Ae. aegypti, based on the detection of mosquito larval foci. Thus, breeding sites treated with PPF, in which the larvae remain alive, may lead to incorrect estimates of mosquito infestation levels, as well as the possibility of overlapping treatment of Ae. aegypti larval foci.

The limitations of this study included delay in obtaining the F1 generation of all populations, due to the very cold weather in 2017, which affected estimates of the dose-response curve. No new assays could be performed with PPF sub-doses to improve standardization of the diagnostic dose curve assays.

New areas of the FD need to be monitored for changes in the susceptibility of Ae. aegypti. Field bioassays with Ae. aegypti populations from DF will also contribute to understanding the effectiveness of PPF in the field.

\section{ACKNOWLEDGMENTS}

We wish to thank the ROGAMA/NEOGEN® COMPANY and Murilo Amaral, a sales representative of the company, for supplying the chemical product, 97\% technical Pyriproxyfen. Thanks are also due to the Directorate of Environmental Surveillance - DIVAL of the Federal District.

\section{AUTHORS' CONTRIBUTIONS}

BLC: coordinated and collected biological material (Ae. aegypti eggs) in the field, organized bioassays, analyzed statistical data, and drafted the manuscript; KMLB and ERFA: assisted in collecting biological material (Ae. aegypti eggs) in the field and in the maintenance of Ae. aegypti colonies in the laboratory; RNLG: assisted in bioassays and in the maintenance of Ae. aegypti colonies in the laboratory; DAR assisted in the statistical analysis and critically reviewed the manuscript; MTO: designed and coordinated all field activities, experiments, analyses, and critically reviewed the manuscript. We declare that all authors have read and approved the final version of the manuscript.

\section{CONFLICT OF INTERESTS}

The authors declare that they have no conflicting interests regarding the publication of this article.

\section{FINANCIAL SUPPORT}

Financial support was provided by the Fundação de Apoio à Pesquisa do Distrito Federal/FAP/DF, Edital 04/2016 and Coordenação de Aperfeiçoamento de Pessoal de Nível Superior (CAPES).

\section{REFERENCES}

1. Organização Pan-Americana da Saúde (OPAS). Organização Mundial da Saúde (OMS). Zika Epidemiological Update - 9 junho 2016. Washington: OPAS/OMS; 2016. 4 p.

2. Camara TNL. Emerging arboviruses, and new challenges for public health in Brazil. Rev Saude Publica. 2016;50(36):1-7.

3. Renteria BL, Troupin A, Colpitts TM. Arbovisose and potential transmission-blocking vaccines. Parasit Vectors. 2016;9(516):1-11.

4. Leta S, Beyene TJ, Clercq EM, Amenu K, Kraemer MUG, Revie CW. Global risk mapping for major diseases transmitted by Ae. aegypti and Aedes albopictus. Int J Infect Dis. 2018;67:25-35.

5. Zara ALSA, Santos SM, Oliveira ESF, Carvalho RG, Coelho GE. Estratégias de controle do Ae. aegypti: uma revisão. Epidemiol Serv Saude. 2016;25(2):391-404.

6. Barbosa A, Silva MAN. Preferência por local de oviposição de Aedes albopictus (Skuse) (Diptera, Culicidae), em relação à presença de imaturos da própria espécie, sob condições de laboratório. Rev Bras Zool. 2002;19(4):1147-52.

7. Silva VC, Freire NMS, Silva JS, Scherer PO, Cunha SP, Alencar J. Estudo comparativo entre larvitrampas e ovitrampas para avaliação da presença de Ae. aegypti (Diptera: Culicidae) em Campo Grande, Estado do Rio de Janeiro. Rev Soc Bras Med Trop. 2009;42(6):730-1.

8. Tauil PL. Aspectos críticos do controle do dengue no Brasil. Cad Saude Publica. 2002;18(3):867-71.

9. Carvalho FD, Moreira LA. Why is Ae. aegypti Linnaeus so Successful as a Species?. Neotrop Entomol. 2017;46(3):243-55.

10. Donalísio MR, Glasser CM. Vigilância Entomológica e Controle de Vetores do Dengue. Rev Bras Epidemiol. 2002;5(3):259-71.

11. Kraemer MUG, Sinka ME, Duda KA, Mylne AQN, Shearer FM, Barker $\mathrm{CM}$, et al. The global distribution of the arbovirus vectors Ae. aegypti and Aedes albopictus. J Life Sci. 2015;30(4):1-18.

12. Carvalho MSL, Caldas ED, Degallier N, Vilarinhos PTR, Souza LCKRIV, Yoshizawa MAC, et al. Susceptibility of Ae. aegypti larvae 
to the insecticide Temephos in the Federal District, Brazil. Rev Saude Publica. 2004;38(5):623-9.

13. Braga IA, Valle D. Ae aegypti: histórico do controle no Brasil. Epidemiol Serv Saude. 2007;16(2):113-8.

14. Lima EP, Paiva MH, Araújo AP, Silva EV, Silva UM, Oliveira LN, et al. Insecticide resistance in Ae. aegypti populations from Ceará, Brazil. Parasit Vectors. 2011;4(5):1-12.

15. Bellinato DF, Viana-Medeiros PF, Araújo SC, Martins AJ, Lima JBP, Valle D. Resistance status to the insecticides Temephos, Deltamethrin, and Diflubenzuron in Brazilian Ae. aegypti populations. BioMed Res Int. 2016;2016:12 p.

16. Moyes CL, Vontas J, Martins AJ, Ng LC, Koou SY, Dusfour I, et al. Contemporary status of resistance to insecticides in the main vectors Aedes arbovirus infecting humans. PLoS Negl Trop Dis. 2017;11(7):120.

17. De Sá ELR, Rodovalho CM, Sousa NPR, Bellinato DF, De Sá ILR, Dias LS, et al. Evaluation of insecticide resistance in Ae. aegypti populations connected by roads and rivers: the case of Tocantins state in Brazil. Mem Inst Oswaldo Cruz. 2019;114:1-10.

18. Valle D, Diogo Fernandes Bellinato DF, Viana-Medeiros PF, Lima JBP, Junior AJM. Resistance to Temephos and deltamethrin in Ae. aegypti from Brazil between 1985 and 2017. Mem Inst Oswaldo Cruz. 2019;114:1-17.

19. Monnerat R, Dumas V, Ramos F, Pimentel L, Nunes A, Sujii E, et al. Evaluation of Different Larvicides for the Control of Ae. aegypti (Linnaeus) (Diptera: Culicidae) under Simulated Field Conditions. Soc Ent Bras. 2012;7(3):1-4.

20. Ministério da Saúde (MS). Secretaria de Vigilância em Saúde. Ofício -Circular no. 14/2017-GAB/SVS/MS. Nota informativa $n^{\circ}$ 013/2017 CGPNCMD/DEVIT/SVS com instruções para emprego do larvicida Pyriproxyfen G 0,5\%. Brasília: MS; 2017. 1 p.

21. Secretaria de Saúde (SES/DF). Diretoria de Vigilância Ambiental em Saúde (DIVAL). Gerência de Vigilância em Vetores e Animais Peçonhentos e Ações de Campo. Memorando Circular Nº 03/2016. GDF. Distrito Federal: SES/DF; 2016. 1 p.

22. Fay RW, Perry AS. Laboratory studies of ovipositional preferences of Ae. aegypti. Mosq News. 1965;25(3):276-81.

23. Depoli PAC, Zequi JAC, Nascimento KLC, Lopes J. Eficácia de Ovitrampas com Diferentes Atrativos na Vigilância e Controle de Aedes. Entomo Brasilis. 2016; 9 (1):51-4.

24. Nunes LS, Trindade RBR, Souto RNP. Avaliação da atratividade de ovitrampas a Aedes (Stegomyia) aegypti Linneus (Diptera: Culicidae) no bairro Hospitalidade, Santana, Amapá. Bio Amazônia. 2011;1(1):2631.

25. Consoli RAGB, Oliveira RL. Técnicas. Routraut AGB. Consoli RL, Oliveira RL. Principais Mosquitos de Importância Sanitária no Brasil. $1^{\circ}$ ed. Rio Janeiro: FIOCRUZ; 1994. p. 161-167.

26. Silva VC, Freire NMS, Silva JS, Scherer PO, Cunha SP, Alencar J. Estudo comparativo entre larvitrampas e ovitrampas para avaliação da presença de Ae. aegypti (Diptera: Culicidae) em Campo Grande, Estado do Rio de Janeiro. Rev Soc Bras Med Trop. 2009;42(6):730-1.

27. World Health Organization (WHO). Monitoring and managing insecticide resistance in Aedes mosquito populations. Interim guidance for entomologists. WHO,/ZIKV/VC/. Genova: WHO; 2016. 13 p.

28. Lau KW, Chen CD, Lee HL, Rashid YN, Azirun MS. Evaluation of Growth Regulators of Insects Against Ae. aegypti and Aedes albopictus Collected in Field (Diptera: Culicidae) from Malaysia. J Med Entomol. 2015;52 (2):199-206.
29. LeOra Software. Polo-PC: a user's guide to probit or logic analysis. Version 2.0. Berkeley, CA: LeOra Software; 2002.

30. Raymond M. Presentation d'une programme d'analyse logprobit pour microordinateur. Cahiers Orstrom Ent Med Parasitol.1985;23(2):117-21.

31. Leyva YR, Coto MMR, Lazcano JL, Insueta OP, Valdés LS. Eficacia del pyriproxyfen para el control de Aedes (S) aegypti (Diptera: Culicidae) en cepas con diferentes niveles de resistencia a temefos. Rev Cubana Med Trop. 2010;62(3):224-9.

32. Ochipinti GM, Berti J, Guerra LA, Salazar M, Escobar CZ, Gómez JA. Efecto del regulator de crecimiento pyriproxyfen sobre Ae. aegypti (Linnaeus, 1762) (Diptera: Culicidae) de la Pedrera, Maracay, estado Aragua, Venezuela. Boletín de Malariología Y Salud Ambiental. 2014;54(2):208-19.

33. Gomes AC. Medidas dos Níveis de Infestação Urbana para Aedes (Stegomyia) aegypti e Aedes (Stegomyia) albopictus em Programa de Vigilância Entomológica. IESUS. 1998;7(3):49-57.

34. Graphpad Prism. User's guide version 6.1: the fast, organized way to analyze and graph scientific data. San Diego. 1999.

35. Andrighetti MTM, Cerone F, Rigueti M, Galvani KC, Macoris MLG. Effect of pyriproxyfen in Ae. aegypti populations with different levels of susceptibility to the organophosphate Temephos. Dengue Bulletin. 2008;32:186-98.

36. Marcombe S, Darriet F, Agnew DP, Etienne M, Yp-Tcha MM, Yébakima A, et al. Field Efficacy of New Larvicide Products for Control of MultiResistant Ae. aegypti Populations in Martinique (French West Indies). J Trop Med. 2011;84(1):118-126.

37. Marcombe S, Farajollahi A, Healy SP, Clark GG, Fonseca DM. Insecticide Resistance Status of United Status Populations of Aedes albopictus and Mechanisms Involved. PLoS One. 2014;9(7):1-10.

38. Garcia GA, David MR, Martins AJ, Maciel-de-Freitas R, Linss JGB, Araujo SC, et al. The impact of insecticide applications on the dynamics of resistance: The case of four Aedes aegypti populations from different Brazilian regions. PLOS Neg Trop Diseases. 2018;12:1-20.

39. Fonseca EOL, Macoris MLG, Santos RF, Morato DG, Isabel MDSS, Cerqueira NA, et al. Estudo experimental sobre a ação de larvicidas em populações de Ae. aegypti do município de Itabuna, Bahia, em condições simuladas de campo. Epidemiol Serv Saude. 2019;28(1):1-9.

40. Braga IA, Mello CB, Peixoto AA, Valle D. Evaluation of Methoprene effect on Ae. aegypti (Diptera: Culicidae) development in laboratory conditions. Mem Inst Oswaldo Cruz. 2005;100(4):435-40.

41. Seccacini E, Lucia A, Harburguer L, Zerba E, Licastro S, Masuh H. Efficacy of the formulations of pyriproxyfen and diflubenzuron as larvicides Against Ae. aegypti. J Am Mosq Control Assoc. 2008;24(3):398-403.

42. Suman DS, Farajollahi A, Healy S, Williams GM, Wang Y, Schoeler $\mathrm{G}$, et al. Point-source and area-wide field studies of pyriproxyfen autodissemination against urban container-inhabiting mosquitoes. Acta Tropica. 2014;135:96-103.

43. Chena CD, Andy-Tana WA, Lokea SR, Lee HL, Yasmin AR, SofianAzirun M. Effectiveness of pyriproxyfen-controlled release block against larvae of Aedes (Stegomyia) aegypti in Kuala Lumpur, Malaysia. Dengue Bull. 2008;32:199-206.

44. Ministério da Saúde (MS). Secretaria de Vigilância em Saúde Departamento de Vigilância das Doenças Transmissíveis. Levantamento Rápido de Índices para Aedes aegypti (LIRAa) para vigilância entomológica do Aedes aegypti no Brasil: metodologia para avaliação dos índices de Breteau e Predial e tipo de recipientes. Brasília: Ministério da Saúde, 2013. 84 p. 